(RESEARCH ARTICLE)

\title{
Struggle against corona-virus in Nepal: Present scenario
}

\author{
Esha Shrestha ${ }^{1}$, Tapas Pramanik ${ }^{2}$ and Tapas Kumar Sur ${ }^{3,}{ }^{*}$ \\ ${ }^{1}$ Lecturer, Department of Physiology, National Medical College, Birgunj, Nepal. \\ 2 Professor, Department of Physiology, Nepal Medical College, Kathmandu, Nepal. \\ ${ }^{3}$ Research Scientist, Multidisciplinary Research Unit, R.G. Kar Medical College, Kolkata, India.
}

Publication history: Received on 26 November 2020; revised on 05 December 2020; accepted on 07 December 2020

Article DOI: https://doi.org/10.30574/wjarr.2020.8.3.0463

\begin{abstract}
Nepal is a South Asian multi-ethnic (125 distinct ethnic groups) country with nearly 30 million populations and located (latitudes $20^{\circ}$ and $31^{\circ} \mathrm{N}$ and latitude $80^{\circ}$ and $89^{\circ} \mathrm{E}$ ) largely in the Himalayas and partly in Indo-Gangetic plain, surrounded by China and India. International tourism is the leading industry in Nepal and around 1.75 million foreigners visit in every year. The first Novel corona virus disease (COVID-19) case was detected in Nepal on January 5 , 2020. After that Government of Nepal immediately took some drastic steps to prevent the spread of COVID-19 like mandatory health check-up in airports, cancellation of visas, prevention of infiltrations in borders, sending back all foreigners/tourists in their home countries and also reformed their healthcare systems, by building up isolation centers in hospitals and involving trained personnel for the management of COVID-19. Besides that, they tried earnestly to educate public through media and imposed/ implemented rule for home quarantine. All these planning to fight against COVID-19 were implemented strictly and granted rewarding results in this pandemic. Till mid-November, 2020 the incidence of COVID-19 infection in Nepal was 208299, of whom, 1215 died.
\end{abstract}

Keywords: Nepal; Pandemic; Coronavirus; COVID-19; RT-PCR

\section{Introduction}

Novel corona virus disease (COVID-19) that emerged from the wet market of Wuhan, Hubei province, China and first detected in December 2019; affected the normal life of mankind all over the world [1]. It took the toll of a huge number of human lives even in developed countries. WHO declared it as a Public Health Emergency of International Concern [2]. Researchers all over the world are earnestly trying to develop vaccine or/and medicine effective against this virus. As such, no treatment is available still now.

Common symptoms of COVID-19-affected patients are fever, cough, myalgia, fatigue, pneumonia and complicated dyspnea. Less Common symptoms are headache, diarrhea, hemoptysis, runny nose, phlegm-producing cough [3,4]. Pulmonary infiltrate in chest radiography, decrease in WBC count, especially lymphocyte count and no improvement in symptoms after 3 days treatment with antibiotic clinically indicate the COVID-positive case [5]. For suspected cases real time fluorescence (RT-PCR) to detect positive nucleic acid of SARS-CoV2 in sputum, throat-swab and secretion of lowerrespiratory tract samples has been recommended [6]. Regarding the infected patients with COVID-19 symptomatic treatment and supportive care has been recommended $[3,4]$. To reduce nosocomial infection knowledge-training for prevention and control, isolation, disinfection, classified protection of different degrees in infected areas and protection of confirmed cases were suggested [7-9]. Experts opined psychological intervention for confirmed cases, suspected cases and medical staff $[7,10]$ The main 3 routes by which the virus can be transmitted are: Droplet transmission: When respiratory droplets from cough or sneeze of infected persons are inhaled or ingested by a person nearby in close proximity. Contact transmission: It occurs when person touches a surface or object contaminated with virus and

\footnotetext{
${ }^{*}$ Corresponding author: Tapas Kumar Sur

Research Scientist, Multidisciplinary Research Unit, R.G. Kar Medical College, Kolkata, India.
} 
subsequently touches their mouth, nose or eyes. Aerosol transmission: When respiratory droplets mix in air and makes aerosol and high dose of aerosol is inhaled by the individual in a closed environment [11]. Virus may enter through digestive system also, as nCoV-S glycoprotein of COVID 19 attaches very quickly to up-regulated ACE-2 receptors of ileum enterocytes of COVID infected patients [12]. The Director General of WHO suggested to increase immunity by adapting balanced diet, regular exercise and to avoid watching television news regularly and repeatedly to get rid of the panic that affects mental health badly.

Here we tried to focus, in this time of crisis how Nepal, a small Himalayan country is preventing the spread of this deadly disease, although in most part of this land plenty of medicines, face-masks and other health facilities are not available. Still, till now small number of persons died here due to COVID-19 infection in comparison to other parts of the world. It reflects the health consciousness of common people in this country and the heroic gesture of the administration against COVID-19 facilitated by the law enforcement, hospital managements, physicians-nurses-health workers, laboratory technicians, and telecommunication that awakened the awareness through all sorts of media.

\section{Material and methods}

Updated information/data/tables, severity of disease, quality of health care through case fatality rate (the number of deaths divided by the number of confirmed cases) [13] - all were studied through websites and regular media briefings/situation reports provided by WHO and Government of Nepal from time to time [14,15]. The Ministry declared situation reports almost every day since 28 January [15]. By focusing on confirmed cases and deaths, the data for this research were obtained from those media briefings and situation updates. Based on cases detected through surveillance and using crude methods, (the number of deaths divided by the number of confirmed cases) case fatality rate is calculated [13].

\section{Results and discussion}

Case Fatality Rates help us to understand the severity of a disease, identify at-risk populations, and evaluate quality of health care [13]. The media briefings and situation reports explained the major activities of the Government aimed at curbing the disease and the current status of infections, hospitalizations and deaths.

Nepal has reduced mortality by providing appropriate clinical care for those affected by COVID-19, ensuring continuity of essential health \& social services. At present around the 216 countries more than 4.5 million people are infected and $3,07,537$ casualties are reported due to COVID-19 [16]. There is at least one casualty from this virus every 15 seconds [17].

\subsection{Present scenario of Fatality rate}

The average fatality rate due to corona-virus is 3.5\% globally; $3.8 \%$ in UK, $2.45 \%$ in the United State and $1.4 \%$ in India. On the other hand, the fatality rate in Nepal is even lower than $0.58 \%$ [18].

On 24 March, 2020, when the nationwide lockdown was imposed in Nepal, there were only two COVID-19 infected patients. In a period of just four months, the number of confirmed cases spiked to over 17,000 with 40 deaths. A month since the lockdown was lifted partially, as of on 26 August, the COVID-19 infected cases doubled to 34,418 while the death toll reached 175 in the country [17]. Now in mid-November, the COVID infected case increases to 208299 while death rate is only 1215 [18]. Instead of tremendous effort from the Government of Nepal, public and the individuals to control the spread of the virus and treatment of the infected cases, a good number of cases were detected in Nepal but the mortality rate is lower than India and much lower than several European countries like UK and Italy. It may be due to a greater number of young people in Nepalese population. High risk group (comorbidity/old age) here is also less affected than those in European countries as shown in Table 1. 
Table 1 Age-specific case fatality ratio and death in COVID-19 confirmed case(N=10096)

\begin{tabular}{|l|l|l|l|l|l|}
\hline Age Group & $\begin{array}{l}\text { Total confirmed } \\
\text { cases }\end{array}$ & Death(male) & Death(Female) & $\begin{array}{l}\text { Death with known } \\
\text { comorbid } \\
\text { condition }\end{array}$ & $\begin{array}{l}\text { Age } \\
\text { case } \\
\text { ratio (\%) } \\
\text { fatality }\end{array}$ \\
\hline 0-4 years & 146 & 0 & 1 & 0 & 0.68 \\
\hline 5-9 years & 132 & 1 & 0 & 0 & 0.76 \\
\hline 10-19 years & 1935 & 1 & 0 & 1 & 0.05 \\
\hline 20-29 years & 4141 & 2 & 1 & 1 & 0.07 \\
\hline 30-39 years & 2215 & 3 & 0 & 1 & 0.14 \\
\hline 40-49 years & 1018 & 4 & 2 & 3 & 0.59 \\
\hline 50-59 years & 355 & 4 & 0 & 3 & 1.13 \\
\hline 60-69 years & 91 & 3 & 0 & 3 & 3.3 \\
\hline 70-79 years & 24 & 2 & 0 & 2 & 8.33 \\
\hline 80+ years & 8 & 0 & 0 & 0 & 0 \\
\hline Unknown & 31 & 0 & 0 & 0 & 0 \\
\hline Grand Total & 10096 & 20 & 4 & 14 & 0.24 \\
\hline
\end{tabular}

Table 2 COVID 19 confirmed case, death rate and case fatality rate of countries as of 15 November 2020

\begin{tabular}{|l|l|l|l|}
\hline Country & Confirmed Case & Death & Case Fatality rate \\
\hline Nepal & $2,08,299$ & 1,215 & $0.50 \%$ \\
\hline India & $8,814,579$ & 129,635 & $1.47 \%$ \\
\hline US & $10,641,431$ & 242,542 & $2.24 \%$ \\
\hline Canada & 287,318 & 10,828 & $3.76 \%$ \\
\hline UK & $1,344,360$ & 51,766 & $3.85 \%$ \\
\hline Italy & $1,144,552$ & 44,683 & $3.90 \%$ \\
\hline China & 92.428 & 4,749 & $5.13 \%$ \\
\hline
\end{tabular}

The best way of prevention is to avoid the exposure of COVID-19 affected persons as no vaccine against this virus is discovered yet [19]. According to WHO guidelines about the use of face-masks, Health-care workers are recommended to use particulate respirators such as those certified N-95 or FFP2, when performing the aerosol generating procedure. They must use medical masks while providing any care to suspected or confirmed cases. Individuals with respiratory symptoms are advised to use medical masks both in health care and homecare setting properly following infection prevention guidelines. Individuals without respiratory symptoms were not required to wear a medical mask when in public. Proper disposal of masks is important to avoid any increase in risk of transmission [20]. One must cover mouth and nostrils with tissues while coughing and sneezing. Those used tissues must be disposed in a covered litter-bin. If no tissue is available, one must cover mouth and nostrils with his/her flexed elbow. Regular hand wash with soap or disinfection with hand sanitizer containing at least $70 \%$ alcohol (if soap and water is not available), avoidance of contact with infected people, maintaining an appropriate distance as much as practicable and refraining of from touching eyes, nose and mouth with unwashed hand were recommend by Chinese Centre for Disease Control and Prevention [3]. 


\subsection{Measures taken by the Government of Nepal}

Now, let us try to brief about the measures taken by the Government of Nepal to prevent the spread of the deadly virus. In March 12, 2020, WHO announced COVID-19 outbreak as a pandemic. The government of Nepal immediately suspended all arrival tourist visas and restricted international flights. In March 24, 2020, government declared countrywide lock down and till date government strictly maintained it. Further, the lock-down and home quarantine was extended up to May 18, 2020. Citizens are allowed only 3 hours, from 6-9AM to procure and sell the essential commodities. Wearing masks are compulsory, when in outside. Shop-keepers are using mask and surgical rubber-gloves and keeping safe distance from the buyers. Most of the petrol-pumps are closed, very few opens for half-an hour to one hour or so within the time period of 6-9AM, morning. Online classes were continuing in academic institutions; both students and faculty members are in home quarantine. In hospitals special fever clinic are in action for primary screening of suspected cases. Quarantine centers and hospitals were set up across the country. Health professionals were trained. At present, nineteen (19) COVID-19 detecting laboratories are functioning throughout Nepal for RT-PCR tests [21]. Government have been prepared 58179 beds for quarantine and 3304 beds for isolation.

Besides, the instruction and awareness appeal through television for washing hands frequently using soap and water and using alcohol-based sanitizer to sterilize hands, for months together if one dials a mobile number having SIM-card active within Nepal, instead of ringtone the precaution measures against the spread of deadly corona virus, a zoonotic, enveloped single-stranded RNA virus [22] is audible through mobile-phone in Nepali language. Nepal Telecom - telecommunication of the Government, through mobile sent message requesting the people of the country to inform about COVID 19 infection case by dialing *1419\# and then by responding to the question put forward by selecting option 1 or 2 . In this way they are always trying to make and keep people alert for preventing the spread of COVID-19 infection and requesting people to stay safe.

\section{Conclusion}

Considering the all facts, it might be concluded that the mainland Nepal still holds the position of a conqueror in the battle against COVID-19 with its healthcare management, which has been clearly reflected by low fatality rate and reduced number of deaths in comparison to other countries.

\section{Compliance with ethical standards}

\section{Acknowledgments}

We would like to offer our special thanks and gratitude to all the health professionals of Nepal for their tireless endeavor to fight against deadly coronavirus.

\section{Disclosure of conflict of interest}

All certified that they have NO affiliations with or involvement in any organization or entity with any financial interest or non-financial interest in the subject matter or materials discussed in this manuscript.

\section{References}

[1] Zhu N, Zhang D, Wang W, Li X, Yang B, Song J et al. A novel corona virus from patient with pneumonia in China. 2019 N Eng J Med. 2020.

[2] Statement on the second meeting of The International Health Regulation (2005) Emergency Committee regarding the outbreak of novel corona virus (2019-nCoV) 2020. Geneva: World Health Organization. 2020.

[3] CDC. 2019 Novel corona virus, Wuhan, China. 2020.

[4] Huang C, Wang Y, Li X, Ren L, Zhao Jianping, Hu Y, et al. Clinical features of patients infected with 2019 novel coronavirus in Wuhan, China. Lancet. 2020; 395:497-506.

[5] Li Q, Guan X, Wu P, Wang X, Zhou L, Tong Y et al. Early transmission dynamics in Wuhan, China of novel corona virus infected pneumonia. N Eng J Med. 2020.

[6] Li T, Wei C, Li W, Hongwei F, Shi J. Beijing Union Medical College Hospital on, 'Pneumonia of novel corona virus infection' diagnosis and treatment proposal (V2.0). Med J Peking Union Med Coll Hosp. 2020. 
[7] Wang C, Wang X. Prevalence, nosocomial infection and psychological prevention of novel corona virus infection. Chin General Pract Nurs. 2020; 18:2-3.

[8] Wei Q, Ren Z. Disinfection measures for pneumonia foci infected by novel corona virus in 2019. Chin J Disinfect. 2020; 37:59-62.

[9] Bin C, Fang X, Chen H. Application effect of disaster vulnerability analysis in coping with the transmission of new corona virus in non-closed hematology ward. 2020.

[10] Xu M, Zhang Y. Investigation on the psychological status of the first batch of clinical first line support nurses to fight against pneumonia caused by novel corona virus. Chin Nurs Res. 2020; 34:1-3.

[11] National Health Commission of Peoples Republic of China: Prevent guideline of 2019-nCoV. 2020.

[12] Zhang H, Kang Z, Gong H, Xu D, Wang J, Li Z. et al. The digestive system is a potential route of 2019-nCoV infection: a bio-informatics analysis based on single cell transcriptomes. bioRxiv. 2020.

[13] Estimating mortality from COVID-19. Scientific briefs. World Health Organization. 2020.

[14] Government of Nepal Ministry of Health and Population. Novel corona virus (COVID-19) media briefing. 2020.

[15] Government of Nepal Ministry of Health and Population. Health sector response to COVID-19. Sit Rep. 2020;1183.

[16] Coronavirus disease (COVID-19) outbreak situations. Geneva: World Health Organization. 2020.

[17] Jha HB. Containing COVID 19 crisis in Nepal. Observer Research Foundation. 2020.

[18] COVID 19 Epidemiological Update. World Health Organization.15 November 2020.

[19] Ou F, Wu H, Yang Y, Tan W, Zhang , Gu J. Countermeasures for rapid spread of new corona virus pneumonia in Wuhan. Chin General Pract Nurs. 2020.

[20] Advice on the use of masks in the community, during home care and health care settings in the context of the novel corona virus 2019-nCoV outbreak (Interim guidance) $2020 \mathrm{WHO/nCoV/IPC-masks/2020.} \mathrm{Geneva:} \mathrm{World}$ Health organization. 2020.

[21] Coronavirus disease (COVID-19) outbreak updates \& resource materials. Govt. of Nepal, Ministry of Health and Population. \# Report 19.

[22] Adhikary SP, Meng S, Wu Y, Mao Y, Ye R, Wang Q, Sun C, Sylvia S, Rozelle S, Raat H, Zhou H. Epidemiology, causes, clinical manifestation and diagnosis, prevention and control of corona virus disease (COVID-19) during the early outbreak period: a scooping study. Infectious Diseases of Poverty. 2020; 9:29-39. 